\title{
Public Health Protection Against Bioterrorism via Respiratory Pathogenic Viral and Bacterial Agents using Protective Face Masks
}

\author{
DAVID BROOKSTEIN, SC.D. ${ }^{1}$ \\ ${ }^{1}$ Department of Mechanical Engineering, Temple University
}

Correspondence: david.brookstein@temple.edu (David Brookstein)

\begin{abstract}
The widespread respiratory transmission of the SARS-COV-2 virus has taught the general public the role that face coverings can play in mitigating the spread of the virus. While vaccines will mitigate widespread viral infection, protective face masks are an important way to prevent respiratory infections from various pathogenic agents. In view of the possibility of respiratory-based bioterrorism or new naturally occurring pathogens in the future, it is possible that the public may have to become comfortable with universal usage of face masks. The Centers for Disease Control recommends that all families have readily available respiratory protection as part of their personal pandemic plan and face masks should be worn by all individuals during a pandemic especially one caused by bioterrorism or an emerging viral or bacterial pathogen. This paper discusses the evolution of protective face masks that capture pathogens, development of face mask. filters which enhance the performance of cloth-based protective facemasks for capturing pathogenic respiratory particles, and protective face masks with filters which capture and kill or deactivate pathogens using silver, copper oxide and zinc oxide-based particles.
\end{abstract}

Keywords: bioterrorism, public health, face mask

\section{Introduction}

Infectious disease disasters are events that involve a biological agent or disease and that can result in mass casualties, such as a bioterrorism attack, a pandemic, or an outbreak of an emerging infectious disease. Infectious disease disasters are different from other types of disasters because they increase the risk of communicable disease spread during and after the incident. Infectious disease disasters include biological terrorism, emerging infectious disease outbreaks, and other pandemics. Common characteristics of this diverse group of biologic agents include the ability to be dispersed in mucosalivary aerosols of 1 to 5 micron-sized particles, which can penetrate the distal bronchioles. Further, once a human is infected by a pathogenic virus it can be transmitted to other humans though respiratory means. There is a high likelihood of such a pandemic occurring in the future and bioterrorism, which is the intentional use of a biological agent or derivative of such an agent to inflict harm or death onto a civilian population, also could occur. ${ }^{1}$ Bacterial or viral pathogens can be weaponized and the biologic agents may be dispersed by several techniques including aerosol sprays. ${ }^{2}$

In 2018, the World Health Organization published a handbook titled "Managing Epidemics". ${ }^{3}$ The handbook offered several critical suggestions. Effective and rapid containment of emerging diseases is just as vital as early detection in order to avoid a large-scale epidemic. Rapid containment should start as 
soon as the first case is detected regardless of the etiology, which is most likely to be unknown. It requires skilled professionals to safely implement the necessary countermeasures. Pre-training of these professionals is essential to guarantee the safety and efficiency of the operations. Once the infectious disease threat reaches an epidemic or pandemic level, the goal of the response is to mitigate its impact and reduce its incidence, morbidity, and mortality as well as disruptions to economic, political, and social systems. $^{3}$ (See Figure 1)

Figure 1. Epidemic phases and response interventions

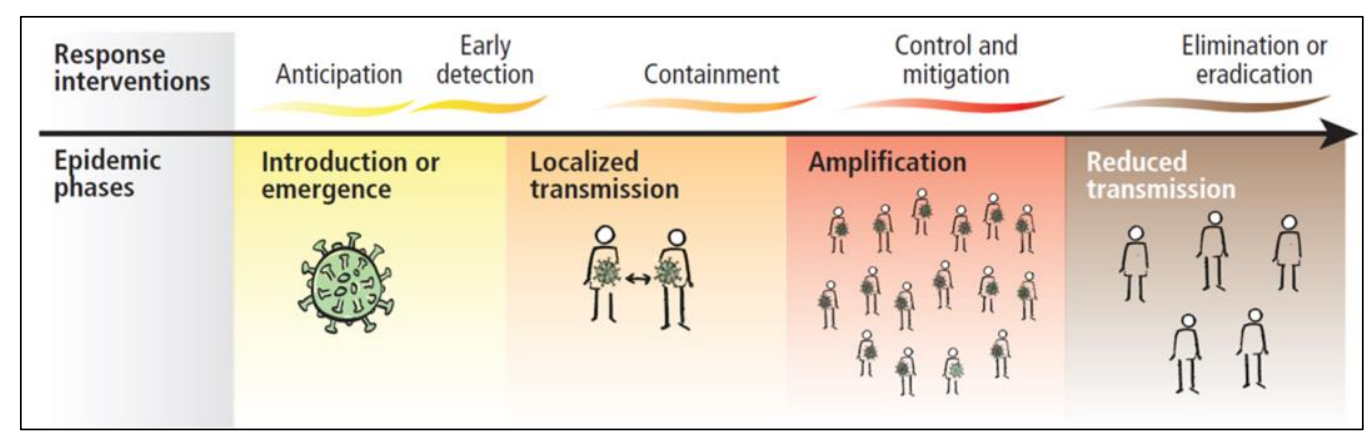

The transmission of pathogenic aerosols can be reduced by wearing face coverings. Different types of coverings offer different degrees of protection. The ultimate goal is to minimize penetration through the porous material of the covering. Penetration usually takes place due to a pressure and concentration gradient across the barrier, respectively. Pathogens, such as the SARS-COV-2 virus, are transmitted most easily through liquids such as mucosalivary aerosols. ${ }^{4}$ These aerosols can be expressed by coughs, sneezes, or just exhaling. ${ }^{5}$ For respiratory pathogens, such as viruses or bacterial, the best way to prevent localized infection and/or mitigate community spread (amplification) are effective protective textile face masks since they can reduce and mitigate airborne transmission. No masking maximizes exposure whereas universal masking results in reducing the exposure via inhalation and transmission via exhalation.

Protective face masks, at the minimum, should provide adequate cover of the wearer's mouth and nose. Further, they should provide a tight fit while still remaining comfortable. Their function is to minimize or even prevent pathogenic-containing mucosalivary secretions from passing through the mask during exhalation and also minimize or even prevent pathogenic respiratory aerosols or droplets exhaled by others from being inhaled. This is referred to as "capturing ability". However, capturing ability, while necessary, is not sufficient to prevent infection from a pathogenic agent. To be optimally effective in mitigating spread of respiratory borne diseases, the mask should also deactivate or kill the pathogenic agents. The ideal mask would be able to both capture and deactivate or kill either of these types of pathogenic agents. Further, the protective mask should be reusable for a period of time and be able to be occasionally cleaned using conventional laundering equipment. The protective mask should have an adequate shelf life so it can be held in reserve for immediate deployment in case of a public health threatening bioterrorism event or a transmission of a naturally occurring emerging pathogen. (See Table 1)

Table 1. Mask Mechanisms to Mitigate Airborne Aerosol Spread of Pathogens

\begin{tabular}{|c|l|l|c|}
\hline RESPIRATORY FUNCTION & \multicolumn{2}{|c|}{ MASK MECHANISM } & $\begin{array}{c}\text { OPTIMAL MASK } \\
\text { MECHANISM }\end{array}$ \\
\hline INHALATION & CAPTURE & DEACTIVATE OR KILL & $\begin{array}{c}\text { CAPTURE AND DEACTIVATE } \\
\text { OR KILL }\end{array}$ \\
\hline EXHALATION & CAPTURE & DEACTIVATE OR KILL & $\begin{array}{c}\text { CAPTURE AND DEACTIVATE } \\
\text { OR KILL }\end{array}$ \\
\hline
\end{tabular}




\section{Evolution of Protective Face Masks That Capture Pathogens}

An N95 respirator, which is widely recognized as the "gold standard" face covering by medical professionals, is designed to achieve a very close facial fit and very efficient filtration of airborne particles. The edges of the respirator are designed to form a seal around the nose and mouth. N95 respirators are commonly used in healthcare settings. They are tested for fluid resistance, filtration efficiency (particulate filtration efficiency and bacterial filtration efficiency), flammability and biocompatibility. ${ }^{6}$

An N95 respirator removes particles from the air that is breathed through it. These respirators filter out at least $95 \%$ of very small ( $<0.3$ micron) particles. N95s are capable of filtering out all types of particles, including bacteria and viruses. ${ }^{7,8}$ (See Figure 2) Melt blowing is a method of producing fibers on the order of $10 \mu \mathrm{m}$ using high production rates without using spinnerets. A thermoplastic polymer is melted and extruded through relatively large holes. As the polymer leaves the extrusion holes it is hit by a high stream of hot air which breaks up the fiber flow and stretches the filaments until they are relatively fine. At a later stage, cold air mixes with the hot air and the polymer solidifies into a fiber.

Figure 2. Schematic of Various Fabric Layers in an N95 respirator

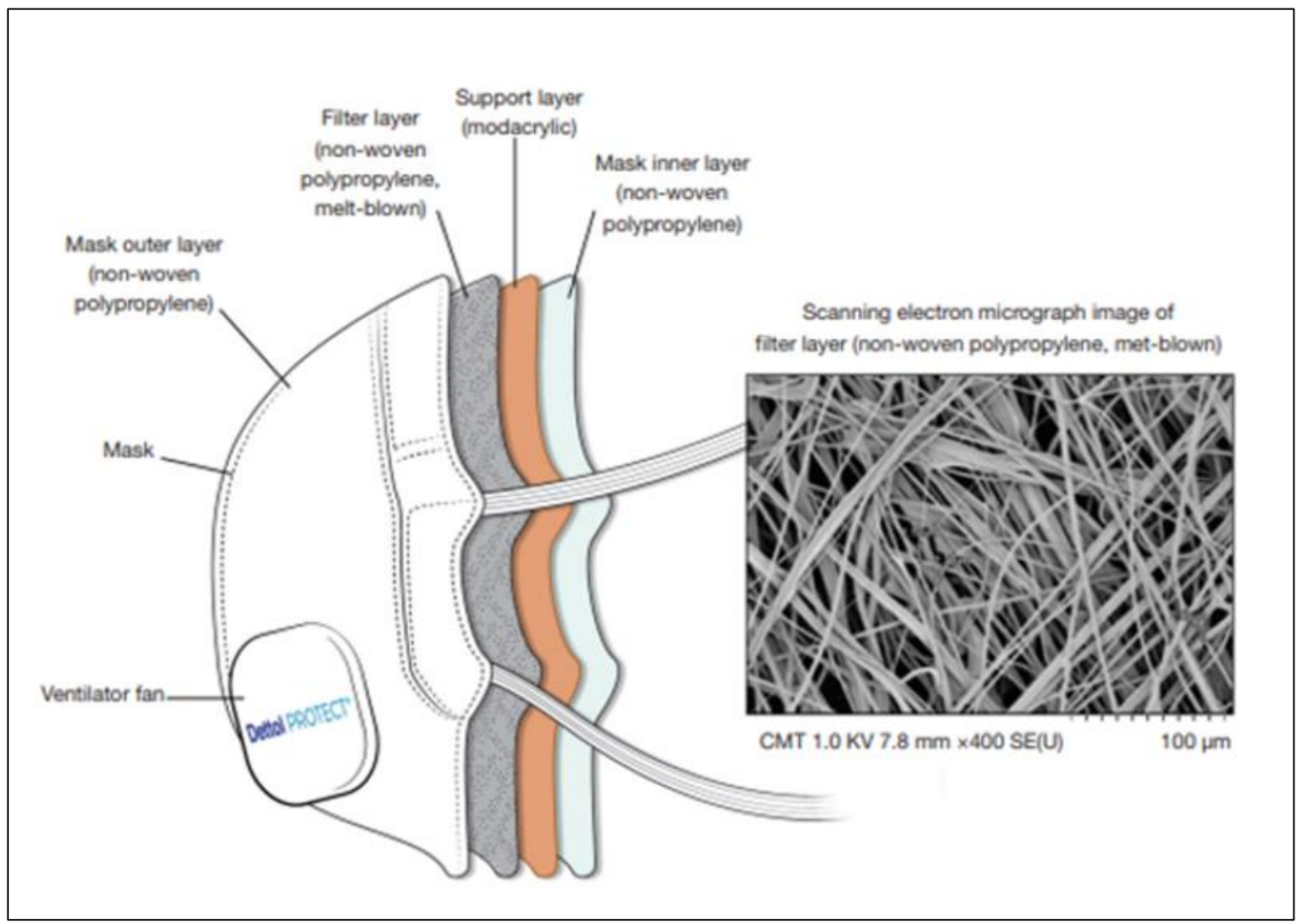

The N95 filter that is included in the N95 respirator is solely designed to capture particles containing pathogens, such as SARS-COV-2, and not deactivate or kill the pathogens. Capturing these particles is a result of 5 different mechanisms: gravity sedimentation, inertial impaction, interception, diffusion, and electrostatic attraction (See Figure 3). ${ }^{9}$ 
Figure 3. Schematic of the Mechanisms of Aerosol Penetration Through Masks

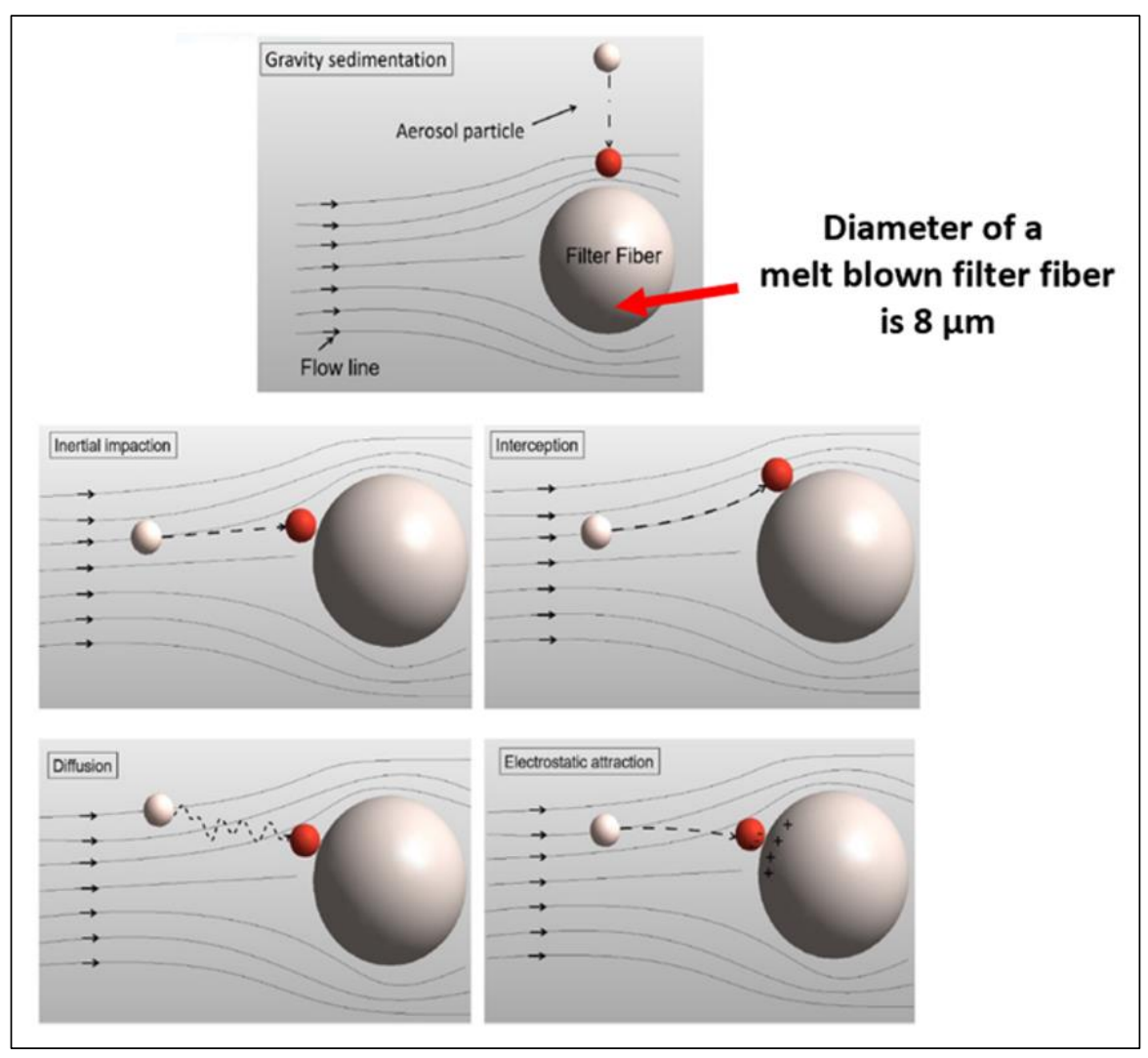

During the initial stages of the SARS-COV-2 pandemic, the use of cloth masks, many of them homemade, became widely prevalent as commercial masks were not readily available. The efficiency of common fabrics used for cloth face masks made from woven fabrics was recently evaluated. ${ }^{10}$ The study presented data of Particulate Filtration Efficiency (PFE) and pressure differential $(\Delta \mathrm{P})$ which is an indication of breathability. The PFE is measured using ASTM Standard F2299 "Standard Test Method For Determining The Initial Efficiency Of Materials Used In Medical Face Masks To Penetration By Particulates Using Latex Spheres."11 For maximizing wearer breathability during exhalation and inhalation, the pressure drop should be as low as possible while maintaining a relatively high particle filtration efficiency. A face mask with relatively high filtration efficiency but physiologically intolerable resistance to airflow is essentially unusable to the wearer. Consequently, both the filter penetration and air resistance should be considered when ranking protective face masks and respirators.

Protective face masks which are purposed to capture aerosolized pathogenic agents should have relatively high-Particulate Filtration Efficiency (PFE). Using the recent data of aerosol filtration efficiency of common fabrics used in respiratory cloth masks from Konda et al. the PFE and pressure drop across the mask material were determined for N95 respirators, surgical masks and a range of woven fabrics for particle sizes $<0.3 \mu \mathrm{m}$ and $>0.3 \mu \mathrm{m}$ (See Table 2). ${ }^{12}$

These data indicate that protective face masks made from surgical masks and conventional cloth fabrics have relatively lower filtration rates than N95 respirators. Nonetheless, N95 respirators and surgical masks are superior to the woven fabric cloth masks that were studied. Fit (how tight the seal is between a mask and the wearer) also plays an important role with regard to affecting the PFE (See Table 3). ${ }^{12}$ 
Table 2. Particle Filtration Efficiencies of Various Test Specimens at a Flow Rate of 1.2 CFM and the Corresponding Differential Pressure $(\Delta \mathrm{P})$ across the Specimen

\begin{tabular}{|c|c|c|c|c|c|}
\hline Type of Mask & $\begin{array}{l}\text { Particle } \\
\text { Efficien }\end{array}$ & $\begin{array}{l}\text { iltration } \\
\text { (PFE), \% }\end{array}$ & $\begin{array}{c}\text { Pressure } \\
\text { Differential }(\Delta \mathrm{P}), \\
\mathrm{Pa}\end{array}$ & $\begin{array}{l}\text { Comparison: } \\
\text { polypropyle }\end{array}$ & $\begin{array}{l}\text { N95 melt } \\
\text { espirator }\end{array}$ \\
\hline & Parti & e Size & & & \\
\hline Particle Size & $<0.3 \mu \mathrm{m}$ & $>0.3 \mu \mathrm{m}$ & & $<0.3 \mu \mathrm{m}$ & $>0.3 \mu \mathrm{m}$ \\
\hline $\begin{array}{l}\text { N95 Respirator-melt } \\
\text { blown } \\
\text { polypropylene fiber }\end{array}$ & 85 & 99.9 & 2.2 & & \\
\hline \begin{tabular}{|l|} 
Surgical Mask -spun \\
bonded polyester
\end{tabular} & 76 & 99.6 & 2.2 & $89.4 \%$ & $99.7 \%$ \\
\hline $\begin{array}{l}\text { Quilter's Cotton - } 2 \\
\text { woven layers }\end{array}$ & 38 & 49 & 2.5 & $44.7 \%$ & $49.0 \%$ \\
\hline $\begin{array}{l}\text { Quilter's Cotton - } 1 \\
\text { woven layer }\end{array}$ & 9 & 14 & 2.2 & $10.6 \%$ & $14.0 \%$ \\
\hline $\begin{array}{l}\text { Flannel }-65 \% \\
\text { cotton/35\%polyester }\end{array}$ & 57 & 44 & 2.2 & $67.1 \%$ & $44.0 \%$ \\
\hline $\begin{array}{l}\text { Chiffon - } 90 \% \\
\text { polyester/10\% } \\
\text { cotton - } 1 \text { woven } \\
\text { layer }\end{array}$ & 67 & 73 & 2.7 & $78.8 \%$ & $73.0 \%$ \\
\hline $\begin{array}{l}\text { Chiffon }-90 \% \\
\text { polyester } / 10 \% \\
\text { cotton - } 2 \text { woven } \\
\text { layers }\end{array}$ & 83 & 90 & 3.0 & $97.6 \%$ & $90.0 \%$ \\
\hline Silk - 1 woven layer & 54 & 56 & 2.5 & $63.5 \%$ & $56.0 \%$ \\
\hline Silk - 4 woven layers & 86 & 88 & 2.7 & $101.2 \%$ & $88.0 \%$ \\
\hline
\end{tabular}

Table 3. Particle Filtration Efficiencies of Various Test Specimens at a Flow Rate of 1.2 CFM and the Corresponding Differential Pressure $(\Delta \mathrm{P})$ across the Specimen (No Gap v. Gap)

\begin{tabular}{|c|c|c|c|c|c|}
\hline \multirow{3}{*}{$\begin{array}{l}\text { Type of Mask } \\
\text { Particle Size } \\
\end{array}$} & \multirow{2}{*}{\multicolumn{2}{|c|}{$\begin{array}{l}\text { Particle Filtration } \\
\text { Efficiency (PFE), \% }\end{array}$}} & \multirow[t]{3}{*}{$\begin{array}{c}\text { Pressure } \\
\text { Differential }(\Delta \mathrm{P}), \\
\mathbf{P a}\end{array}$} & \multirow{2}{*}{\multicolumn{2}{|c|}{$\begin{array}{c}\text { Comparisons of PFE to N95 melt } \\
\text { blown } \\
\text { polypropylene filter respirator }\end{array}$}} \\
\hline & & & & & \\
\hline & $<0.3 \mu \mathrm{m}$ & $>0.3 \mu \mathrm{m}$ & & $<0.3 \mu \mathrm{m}$ & $>0.3 \mu \mathrm{m}$ \\
\hline $\begin{array}{c}\text { N95 Respirator-melt } \\
\text { blown } \\
\text { polypropylene fiber } \\
\text { (No Gap) }\end{array}$ & 85 & 99.9 & 2.2 & & \\
\hline $\begin{array}{c}\text { N95 Respirator-melt } \\
\text { blown } \\
\text { polypropylene fiber } \\
\text { (Gap) }\end{array}$ & 34 & 12 & 2.2 & $40.0 \%$ & $12.0 \%$ \\
\hline $\begin{array}{c}\text { Surgical Mask -spun } \\
\text { bonded polyester } \\
\text { (No Gap) }\end{array}$ & 76 & 99.6 & 2.5 & $89.4 \%$ & $99.7 \%$ \\
\hline $\begin{array}{c}\text { Surgical Mask -spun } \\
\text { bonded polyester } \\
\text { (Gap) }\end{array}$ & 50 & 44 & 2.5 & $58.8 \%$ & $44.0 \%$ \\
\hline
\end{tabular}


Table 4. Comparison of surgical masks to 100\% cotton T-Shirts for B atrophaeus and Bacteriophage MS2 bacterial agents

\begin{tabular}{|l|c|c|c|}
\hline \multicolumn{4}{|c|}{ B atrophaeus bacterial agent } \\
\hline \multicolumn{1}{|c|}{ Mask Material } & $\begin{array}{c}\text { Bacterial Filtration } \\
\text { Efficiency (BFE), \% }\end{array}$ & $\begin{array}{c}\text { Pressure } \\
\text { Differential, } \Delta \mathrm{P} \text { (Pa) }\end{array}$ & $\begin{array}{c}\text { Comparisons of BFE } \\
\text { to spun bonded } \\
\text { surgical mask }\end{array}$ \\
\hline $\begin{array}{l}\text { Surgical Mask -spun bonded } \\
\text { polyester }\end{array}$ & 96.4 & 5.23 & \\
\hline $\begin{array}{l}\text { 100\% Knitted Cotton } \\
\text { T-Shirt fabric - 1 layer }\end{array}$ & 69.4 & 4.29 & $72.0 \%$ \\
\hline $\begin{array}{l}\text { 100\% Knitted Cotton } \\
\text { T-Shirt fabric - 2 layers }\end{array}$ & 70.7 & 5.13 & $73.3 \%$ \\
\hline \multicolumn{1}{|c|}{ Bacteriophage MS2 bacterial agent } \\
\hline \multicolumn{1}{|c|}{ Mask Material } & $\begin{array}{c}\text { Bacterial Filtration } \\
\text { Efficiency (BFE), \% }\end{array}$ & $\begin{array}{c}\text { Pressure } \\
\text { Differential, } \Delta \mathrm{P} \text { (Pa) }\end{array}$ & $\begin{array}{c}\text { Comparisons of BFE } \\
\text { to spun bonded } \\
\text { surgical mask }\end{array}$ \\
\hline $\begin{array}{l}\text { Surgical Mask -spun bonded } \\
\text { polyester }\end{array}$ & 89.5 & 5.23 & \\
\hline $\begin{array}{l}\text { 100\% Knitted Cotton } \\
\text { T-Shirt fabric - 1 layer }\end{array}$ & 50.9 & 4.29 & $56.9 \%$ \\
\hline
\end{tabular}

The efficacy of homemade cloth masks made from knitted cotton fabric, compared to surgical masks, was assessed to determine if they would be effective in an influenza epidemic (H1N1). The results of the study, which compared the bacterial filter efficiency (BFE) and pressure drop, are seen in Table $4 .{ }^{13}$ The efficacy of homemade cloth masks made from knitted cotton fabric, compared to surgical masks, was assessed to determine if they would be effective in an influenza epidemic (H1N1). ${ }^{13}$ The results of the study, which compared the bacterial filter efficiency (BFE) and pressure drop, are seen in Table 4. Bacterial agents were used as proxies for the H1N1 virus, and the data indicate that homemade masks made from knitted cotton fabric should not be used for the reduction of transmission from diseases which can be transmitted via mucosalivary secretions.

Tables 2, 3, and 4 suggest the relative ineffectiveness of masks made from cloth fabrics without filters. Further, the importance of a tight fit between the wearer and the mask is apparent.

\section{Development of Face Mask Filters to Enhance the Performance of Cloth-Based Protective Face Masks for Capturing Pathogenic Mucosalivary Particles}

The particle filtration efficiencies of protective masks made from common woven or knitted fabrics have been shown to have a minimal effect in the filtration of mucosalivary secretions such as those from persons infected with viral and bacterial pathogens. Hence, there is a need to enhance the filtration capability of cloth masks. This can be accomplished with the incorporation of textile materials specifically designed to filter particles such as those expressed by either wearer exhalation or inhalation. Since protective face masks made from conventional woven or knitted fabrics are minimally effective in containing droplets and aerosols when compared to the N95 respirator which has a middle layer comprising a melt blown fibrous filter face mask developers are now recognizing the importance of fibrous filters to substantially reduce the transmission of respiratory induced particles.

Particulate filters have been used in a wide range of other applications. For example, in 1976 a patent was issued for the production of fibrous filters, which was directed at spinning solutions which are electrostatically sprayed and deposited continuously onto a gas permeable band-form support. ${ }^{14}$ In 2006 , a study determined the filtration efficiency of the most penetrating aerosol particles in melt blown fibrous 
filters and nano-electro spun fibrous filters. ${ }^{15}$ Nano-electrospinning is a fiber production method which uses electric force to draw charged threads of polymer solutions or polymer melts up to fiber diameters in the order of less than $1 \mu \mathrm{m}$. Electrospinning uses an electrical charge to draw very fine (typically on the micro or nano scale) fibers from a liquid or polymer solution. Using the procedure for determining the particle filtration efficiencies, four different filters were studied with fiber diameters of $10 \mu \mathrm{m}, 2 \mu \mathrm{m}$, $0.7 \mu \mathrm{m}$, and $0.1 \mu \mathrm{m}$. The researchers found "that utilization of nanofibers to manufacture air filters seems to be an excellent solution from the standpoint of the filter efficiency improvement, especially if the process target is removal of sub micrometer-sized aerosol particles, usually being the hardiest (sic) to filter out."15

Nano-electrospinning has emerged as an effective technique for the fabrication of micro and nanoscale objects, and it is particularly useful in the fabrication of fibrous filters. In the fabrication of filters, nanoelectrospinning has an advantage over traditional technologies, such as melt-blowing, of operating at room temperature. Another significant advantage, and one that is unique to electrospinning, is its ability of producing fibers in the submicron scale. As such, due to their submicron diameter they have a substantially higher surface area to volume ratio than fibers that are produced using the melt blowing process and, as such, are considered more efficient filters. ${ }^{16}$

Researchers in Singapore recently reported that a key factor that affects the function of air filter is fiber diameter and when it is reduced to nanoscale $(<1 \mu \mathrm{m})$ the surface area to volume ratio is relatively high and results in a more effective filter. Nanoscale fibers are commonly produced by nano-electospinning of electrically charged polymer solutions. ${ }^{17}$ There are now many protective face mask manufacturers supplying products with insertable nanoscale fiber filters. For example, HaloMask ${ }^{\mathrm{TM}}$, offers one with an insertable nanofiber filter. ${ }^{18}$ The nanofiber filters were tested for Bacterial Filtration Efficiency (BFE), Differential Pressure $(\Delta \mathrm{P})$ and Particle Filtration Efficiency (PFE). Below are the data for BFE and $\Delta \mathrm{P}$ obtained by the manufacturer of HaloMask ${ }^{\text {TM }}$ using ASTM standards. ${ }^{19,20}$

Table 5. Bacterial Filtration Efficiency and Particle Filtration Efficiency of HaloMask ${ }^{\text {TM }}$

\begin{tabular}{|c|c|c|}
\hline $\begin{array}{l}\text { Bacterial Filtration Efficiency } \\
\text { (BFE) }\end{array}$ & $\begin{array}{l}\text { Pressure Differential, } \Delta P(\mathrm{~mm} \\
\left.\qquad \mathrm{H}_{2} \mathrm{O} / \mathrm{cm}^{2}\right)\end{array}$ & Test Method \\
\hline$\sim 98 \%$ & $\sim 2.0$ & ASTM F2101-19 \\
\hline Particle Size & Particle Filtration Efficiency & Test Method \\
\hline $0.1 \mu \mathrm{m}$ & $\sim 99.0 \%$ & ASTM F2299/F2299M - 03 \\
\hline $0.3 \mu \mathrm{m}$ & $98.8 \%$ & ASTM F2299/F2299M - 03 \\
\hline $0.5 \mu \mathrm{m}$ & $97.8 \%$ & ASTM F2299/F2299M - 03 \\
\hline $1.0 \mu \mathrm{m}$ & $98.0 \%$ & ASTM F2299/F2299M - 03 \\
\hline
\end{tabular}

\section{Masks with Filters Which Capture and Kill or Deactivate Pathogens}

While filtration of pathogenic respiratory agents is necessary to minimize airborne transmission, when filtration is also coupled with pathogenic deactivation a protective face mask will significantly minimize infection of the wearer and thus also minimize transmission to others. Pathogenic deactivation can be affected by various metal-based elements and compounds which can be incorporated into masks or mask filters. 


\section{Silver Particle-Based Deactivation of Pathogens}

A study in the early 2000's was directed at the antimicrobial effect of surgical masks coated with nanoparticles. ${ }^{21}$ The study assessed the antimicrobial activity of nanoparticles (consisting of a mixture of silver nitrate and titanium dioxide) and nanoparticle-coated facemasks to protect against infectious agents. Eschericbia coli and Staphylococcus aureus were used for this study as both are reference strains used for antimicrobial susceptibility testing. The researchers found that masks coated with nanoparticles at low concentrations were effective against E. coli and $S$. aureus, and that bacteria attached to the surface of nanoparticle-treated masks were killed completely. An earlier study showed that impregnation, instead of coating the medical device with nanoparticulate silver metal, improved the antimicrobial activity of the device. This is probably due to the slow and continual release of silver that prolonged the antimicrobial effect. ${ }^{22}$ As such, silver-based antimicrobial formulations and nanoparticles have been identified as effective antibacterial agents. ${ }^{23,24}$ In 2011 it was reported that silver nanoparticles have mainly been studied for their antimicrobial potential against bacteria, but have also proven to be active against several types of viruses including human immunodeficiency virus, hepatitis B virus, herpes simplex virus, respiratory syncytial virus, and monkey pox virus. ${ }^{25}$

Silver-based nanoparticles have been incorporated and functionalized in polyester/cotton fabrics using pad-dry-cure method (a common textile fabric coating process). ${ }^{26}$ This composite proved to be effective for inhibiting the SARS-COV-2 virus, decreasing the number of replicates in $99.99 \%$ after an incubation period of 2 minutes. In addition, it caused $99.99 \%$ inhibition of the bacterial pathogens $S$. aureus, E. coli and C. albicans, preventing cross-infections and does not cause allergies or photo irritation processes, demonstrating the safety of its use..$^{25}$

\section{Copper Oxide-Based Deactivation of Pathogens}

Impregnation of copper oxide into respiratory protective face masks endows them with potent antiinfluenza biocidal properties without altering their physical barrier properties such as breathability. Further, the use of biocidal masks may significantly reduce the risk of hand or environmental contamination, and thereby subsequent infection, due to improper handling and disposal of the masks. The masks were challenged with virus (H1N1) or an aerosolized avian influenza virus (H9N2). The mean (5 masks were tested) Bacterial Filter Efficiency (BFE) was 98.2\%.27

\section{Zinc Oxide Particle-Based Deactivation of Pathogens}

Zinc oxide nanoparticles are antibacterial and inhibit the growth of microorganisms by permeating into the cell membrane. The oxidative stress damages lipids, carbohydrates, proteins, and DNA. ${ }^{28}$ With regard to the antiviral effect of zinc oxide nanoparticles a study was done on the inhibition of H1N1 virus infection. ${ }^{29}$ Zinc oxide nanoparticles and polyethylene glycated zinc oxide nanoparticles were studied. The study showed that polyethylene glycated zinc oxide nanoparticles had a stronger antiviral effect than just zinc oxide nanoparticles.

A patent was recently issued which discloses how zinc oxide nanoparticles can be applied using ultra sonics to coat fabrics. ${ }^{30}$ The patent is being using by Sonovia Ltd. in Israel to produce the SonoMask. ${ }^{31}$ The SonoMask has been tested to be $99.35 \%$ effective against SARS-COV-2, an ability to filter $91 \%$ of $3 \mu \mathrm{m}$ and $95 \%$ of $5 \mu \mathrm{m}$ particles and be able to withstand at least 55 laundering cycles. As such, the SonoMask both captures and deactivates viral pathogens. Further, since the SonoMask can be reused many times it does not significantly contribute to environmental waste. 
Another possibility for creating mask filters which both capture and deactivate viral and bacterial borne pathogens involves nano-electro spinning nanofibers (which have a relatively high surface area to volume ration), such as polyvinylidene difluoride (PVDF) or polyacrylonitrile (PAN), and including in them nanoparticles such as zinc oxide or silver which deactivate viral pathogens and kills bacterial pathogens

\section{Conclusions}

The potential for bioterrorism events that are a result of aerosolized viral and bacterial pathogens exists. We have learned from the SARS-COV-2 pandemic how dangerous aerosolized viral pathogens are and while eventually vaccines may be developed to mitigate the spread of new pathogens, effective protective face masks are an important element that can mitigate the immediate continuous spread and containment of the pathogen. While at first the only widely available masks were cloth-based they proved to be substantially ineffective when compared to the "gold standard" N95 respirator. As the pandemic continued many researchers and companies developed masks that, at first, were only effective in capturing the pathogenic aerosol. Capturing the aerosols with face masks, while useful for protecting the public health, are not as effective until they can also deactivate or kill the pathogen. The CDC recommends that all families have readily available respiratory protection as part of their personal pandemic plan because face masks should be worn by infected individuals when in public places during a pandemic. ${ }^{32}$ This would especially true during a bioterrorism induced pathogenic pandemic or the emergence of new naturally occurring pathogens including SARS-COV-2 variants.

The United States has seen approximately 1500 deaths per million (1.5 in a 1000) of its population as of late February 2021 while Canada has only seen about 580 deaths per million of its population. ${ }^{33}$ American failures have remained dramatic as such questions as wearing masks and how to relax lockdowns have been bitterly politicized. ${ }^{34}$ As such, if the U.S. public is ever threatened by respiratory aerosol pathogenbased bioterrorism attack or another pandemic from an emerging virus, the public will have no choice but to adopt universal mask usage or face the consequences of wide spread infection and death.

Finally, speaking during an online briefing by the WHO in late December 2020, Dr. Mark Ryan, Head of the WHO Emergencies Programme, said that other emerging diseases could be more dangerous than SARS-COV-2. Dr. Ryan said:

This pandemic [SARS-COV-2] has been very severe, it has spread around the world extremely quickly and has affected every corner of this planet - but this is not necessarily the big one. This virus is very transmissible and it kills people and it has deprived so many people of loved ones but its current case fatality is reasonably low compared to other emerging diseases. This is a wakeup call, we are learning now how to do things better. How to do science better, how to do logistics better, how to do training better, how to do governance better, how to communicate better. ${ }^{35}$

\section{Funding Sources}

The author's research was not sponsored by any outside entities. His only source of funding was his regular salary at Temple University College of Engineering. 


\section{References}

1. Rebmann, T., 2020. Infectious Disease Disasters: Bioterrorism, Emerging Infections, and Pandemics. APIC Text Online, Chapter 122 Available from: https://text.apic.org/toc/community-based-infectionprevention-practices/infectious-disease-disasters-bioterrorism-emerging-infections-and-pandemics. Accessed April 4, 2021.

2. Williams M, et al., 2020. Biologic, Chemical, and Radiation Terrorism Review. Available from: https://www.ncbi.nlm.nih.gov/books/NBK493217/

3. Managing Epidemics, 2018, World Health Organization, Available from: https://www.who.int/emergencies/diseases/managing-epidemics-interactive.pdf

4. Guo, Z. et al.,. Aerosol and Surface Distribution of Severe Acute Respiratory Syndrome Coronavirus 2 in Hospital Wards, Wuhan, China. Emerg. 2020 Infect. Dis. 26,7.

5. Lindsley WG, et al., A Cough Aerosol Simulator for the Study of Disease Transmission by Human Cough-Generated Aerosols. Aerosol Sci. Technol. 2013 47,937-944.

6. US FDA, N95 Respirators, Surgical Masks, and Face Masks, 2020, Available from: https://www.fda.gov/medical-devices/personal-protective-equipment-infection-control/n95respirators-surgical-masks-and-face-masks. Accessed December 20, 2020.

7. CDC, Personal Protective Equipment: Questions and Answers. 2020, Available from: https://www.cdc.gov/coronavirus/2019-ncov/hcp/respirator-use-faq.html. Accessed December 20, 2020.

8. Zhou SS, Lukula S, Chiossone C, Nims RW, Suchmann DB, Ijaz MK. Assessment of a respiratory face mask for capturing air pollutants and pathogens including human influenza and rhinoviruses. J Thorac Dis. 2018 Mar;10(3):2059-2069.

9. Tcharkhtchi A, Abbasnezhad N, Zarbini Seydani M, Zirak N, Farzaneh S, Shirinbayan M. An overview of filtration efficiency through the masks: Mechanisms of the aerosols penetration. Bioact Mater. 2020 Aug 11;6(1):106-122.

10. Konda, A. et al., Aerosol Filtration Efficiency of Common Fabrics Used in Respiratory Cloth Masks, ACS Nano 2020, 14, 5, 6339-6347.

11. ASTM Standard F2299-17, "Standard Test Method for Determining the Initial Efficiency of Materials Used in Medical Face Masks to Penetration by Particulates Using Latex Spheres", ASTM International, West Conshohocken, PA.

12. Konda, A. et al., Aerosol Filtration Efficiency of Common Fabrics Used in Respiratory Cloth Masks, ACS Nano 2020, 14, 5, 6339-6347.

13. Davies A, et al., Testing the efficacy of homemade masks: would they protect in an influenza pandemic? Disaster Med Public Health Prep. 2013 Aug;7(4):413-8.

14. Sim, W, inventor; Bayer Aktiengesellschaft, assignee, Apparatus for the production of filters by electrostatic fiber spinning. United States Patent 3,994,258, 1976 Nov 30.

15. Podgórski A. et al, Application of nanofibers to improve the filtration efficiency of the most penetrating aerosol particles in fibrous filters, Chemical Engineering Science 61 (2006) 6804 6815.

16. Ferrer, I. inventor; Donaldson Company, assignee, Fluoropolymer fine fiber, United States Patent 8,978,899, 2015 Mar 17.

17. Chua MH, Cheng W, Goh SS, Kong J, Li B, Lim JYC, Mao L, Wang S, Xue K, Yang L, Ye E, Zhang K, Cheong WCD, Tan BH, Li Z, Tan BH, Loh XJ. Face Masks in the New COVID-19 Normal: Materials, Testing, and Perspectives. Research (Wash D C). 2020 Aug.

18. Available at https://halolife.io/blogs/learn/halo-mask-filtration. Accessed December 21, 2020

19. ASTM F2101-19 "Standard Test Method for Evaluating the Bacterial Filtration Efficiency (BFE) of Medical Face Mask Materials, Using a Biological Aerosol of Staphylococcus aureus”, ASTM International, West Conshohocken, PA. 
20. ASTM Standard F2299-17, "Standard Test Method for Determining the Initial Efficiency of Materials Used in Medical Face Masks to Penetration by Particulates Using Latex Spheres", ASTM International, West Conshohocken, PA.

21. Li Y, Leung P, Yao L, Song QW, Newton E. Antimicrobial effect of surgical masks coated with nanoparticles. J Hosp Infect. 2006 Jan;62(1):58-63.

22. Furno F, Morley KS, Wong B, Sharp BL, Arnold PL, Howdle SM, Bayston R, Brown PD, Winship PD, Reid HJ. Silver nanoparticles and polymeric medical devices: a new approach to prevention of infection? J Antimicrob Chemother. 2004 Dec;54(6):1019-24.

23. Morones JR, et al., The bactericidal effect of silver nanoparticles. Nanotechnology. 2005 $16,2346-53$

24. Kim, JS et al., Antimicrobial effects of silver nanoparticles, Nanomedicine: Nanotechnology, Biology and Medicine, Vol 3, Issue 1,2007, 95-101.

25. Galdiero S, et al., Silver nanoparticles as potential antiviral agents. Molecules. 2011 8894-8918.

26. Tremiliosi GC, Simoes LGP, Minozzi DT, et al. Ag nanoparticles-based antimicrobial polycotton fabrics to prevent the transmission and spread of SARS-CoV-2. bioRxiv. Published online January 1, 2020:2020.06.26.152520. doi:10.1101/2020.06.26.152520

27. Borkow G, Zhou SS, Page T, Gabbay J. A novel anti-influenza copper oxide containing respiratory face mask. PLoS One. 2010 Jun 25;5(6):e11295.

28. Siddiqi KS, Ur Rahman A, Tajuddin, Husen A. Properties of Zinc Oxide Nanoparticles and Their Activity Against Microbes. Nanoscale Res Lett. 2018 May 8;13(1):141.

29. Ghaffari $\mathrm{H}$, et al., Inhibition of H1N1 influenza virus infection by zinc oxide nanoparticles: another emerging application of nanomedicine. J Biomed Sci. 2019 Sep 10;26(1):70.

30. Gedanken, et al., inventor; Bar Ilan University (Ramat Gan, Israel), assignee, Sonochemical coating of textiles with metal oxide nanoparticles for antimicrobial fabrics, United States Patent 10,370,789, 8 Aug 2019.

31. Available at www.sonoviatech.com. Accessed January 3, 2021.

32. Qualls N, Levitt A, Kanade N, et al., Community Mitigation Guidelines to Prevent Pandemic Influenza - United States, 2017. MMWR Recomm Rep 2017, 1-34.

33. Available at https://ourworldindata.org/grapher/covid-deaths-daily-vs-total-permillion?tab $=$ table \&stackMode $=$ absolute $\&$ time $=2020-12-24 \ldots$ latest $\&$ country $=\&$ region $=$ World.

34. Roberts, A., (2020) Pandemics and Politics, Survival, 62:5, 7-40.

35. Available at https://youtu.be/SNXw_gSeGHY accessed on March 12, 2021.

\section{About the Author}

David Brookstein, Sc.D. is Senior Associate Dean and Professor of Mechanical Engineering in the College of Engineering at Temple University. He has an undergraduate degree in textile engineering from Georgia Tech, an MS degree in textile technology and a Doctor of Science degree in the field of Mechanical Engineering from MIT. In addition to serving as an academic, he worked for 14 years as an industrial researcher in the field of textile engineering. He was the Principal Investigator for an eight-year project (Laboratory for Engineered Human Protection) sponsored by the US Department of Defense. He is a Fellow of the American Society of Mechanical Engineers and a Fellow of the Textile Institute (UK). He received the Harold DeWitt Smith Award from the ASTM for Outstanding Achievement in the Science of Textile Fiber Utilization. He is listed as an inventor on 13 US patents in the field of textile/mechanical engineering and bioengineering. He has been studying protective face masks since the beginning of the Covid-19 pandemic. 